\title{
Serology for brucellosis in free-ranging crab-eating foxes (Cerdocyon thous) and brown-nosed coatis (Nasua nasua) from Brazilian Pantanal
}

\author{
Sorologia para brucelose em lobinhos (Cerdocyon thous) e coatis (Nasua nasua) \\ de vida livre do Pantanal Brasileiro
}
Elaine Maria Seles Dorneles ${ }^{I}$ Aiesca Oliveira Pellegrin ${ }^{I I}$ Igor Alexandre Hany Fuzeta Schabib Péres ${ }^{\text {II }}$ Luis Antônio Mathias ${ }^{\text {III }}$ Guilherme Mourão ${ }^{\text {II }}$ Rita de Cassia Bianchiv ${ }^{\text {V }}$ Natalie Olifiers ${ }^{\mathrm{V}}$ Fabiana Lopes Rocha $^{\mathrm{VI}, \mathrm{VII}}$ Andrey Pereira Lage $^{\mathrm{I}^{*}}$

\section{- NOTE -}

\section{ABSTRACT}

A serological survey in free-ranging crab-eating foxes (Canidae: Cerdocyon thous) and brown-nosed coatis (Procyonidae: Nasua nasua) was performed in the Nhecolândia sub-region of the Brazilian Pantanal to evaluate the presence of anti-smooth Brucella antibodies on those wild populations. The detection of anti-smooth Brucella antibodies was performed by the Rose Bengal Test (RBT) as screening test and the Fluorescence Polarization Assay (FPA) as a confirmatory test. The frequency of smooth Brucella seropositive animals were $13.2 \%(5 / 38,95 \%$ CI: $4.4 \%-28.1 \%)$ for crab-eating foxes and $8.8 \%$ (3/34, 95\% CI: $1.9 \%-23.7 \%)$ for brown-nosed coatis. No association was found between seropositivity for brucellosis and gender or age. The results of this study suggest exposure to or infection of crabeating fox and brown-nosed coati from the Brazilian Pantanal by Brucella spp.

Key words: Brazil, Brucella, Pantanal, Cerdocyon thous, Nasua nasua, reservoirs, epidemiology.

RESUMO

Um inquérito sorológico em quatis (Procyonidae: Nasua nasua) e lobinhos (Canidae: Cerdocyon thous) de vida livre foi conduzido na sub-região da Nhecolândia do Pantanal Sulmatogrossense para avaliar a presença de anticorpos anti-
Brucella (fenótipo liso). A pesquisa de anticorpos anti-Brucella foi realizada pelo teste do antígeno acidificado tamponado, utilizado como teste de triagem e pelo teste de polarização fuorescente, utilizado como teste confirmatório. A frequência de animais soropositivos para anticorpos anti-Brucella foi de 13,2\% (5/38, IC 95\%: 4,4\% - 28,1\%) para lobinhos e de 8,8\% (3/34, IC 95\%: $1,9 \%$ - 23,7\%) para coatis. Não foi encontrada associação entre a soropositividade para brucelose e gênero ou idade. Os resultados deste estudo sugerem exposição a ou infecção de lobinhos e quatis do Pantanal Brasileiro por Brucella spp.

Palavras-chave: Brasil, Brucella, Pantanal, Cerdocyon thous, Nasua nasua, reservatórios, epidemiologia.

Brucellosis caused by Brucella spp. is a worldwide distributed zoonosis. It is an important public health problem responsible for direct and indirect losses in animal production (CORBEL et al., 2006). Bovine brucellosis, caused by Brucella abortus, is the most prevalent brucellosis in Brazil (POESTER et al., 2002). It is widespread throughout the territory, with herd prevalences ranging from $0.32 \%$ to $41.5 \%$ (CHATE et al., 2009; SIKUSAWA

\footnotetext{
IDepartamento de Medicina Veterinária Preventiva, Escola de Veterinária, Universidade Federal de Minas Gerais (UFMG), Av. Antônio Carlos 6627, CP 567, 30123-970, Belo Horizonte, MG, Brasil. E-mail: alage@ vet.ufmg.br. *Autor para correspondência.

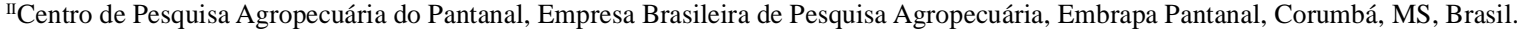

"IIDepartamento de Medicina Veterinária Preventiva e Reprodução Animal, Faculdade de Ciências Agrárias e Veterinárias (FCAV), Universidade Estadual Paulista (UNESP), Jaboticabal, SP, Brasil.

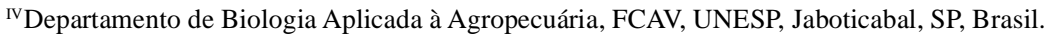

${ }^{v}$ Laboratório de Biologia e Parasitologia de Mamíferos Silvestres Reservatórios, Instituto Oswaldo Cruz, Fundação Oswaldo Cruz (FIOCRUZ), Rio de Janeiro, RJ, Brasil.

VIInstituto Brasileiro para Medicina da Conservação (TRIADE), Recife, PE, Brasil.

VIILaboratório de Ecologia Animal, Universidade Federal da Paraíba (UFPB), Campus IV, João Pessoa, PB, Brasil. Received 08.29.13 Approved 02.25.14 Returned by the author 09.19.14 CR-2013-1167.R2
} 
et al., 2009). Its control and eradication are of the utmost importance to the country.

The success of bovine brucellosis control and eradication programs requires extensive epidemiologic investigation on the presence, participation and importance of the disease in sympatric wildlife, since these may constitute reservoirs able to maintain and transmit Brucella spp. back to adjacent cattle populations (VAN CAMPEN \& RHYAN, 2010). Brucella spp. infection has been reported in different wild species in several countries and environments (GODFROID, 2002) and the transmission is best reported among bison, elks and cattle in the Greater Yellowstone Area (VAN CAMPEN \& RHYAN, 2010).

The Pantanal, the largest freshwater wetland ecosystem in the world, houses a rich and dense wildlife. It has about 160,000 hectares in the center of South America, of which almost $90 \%$ belongs to the Brazilian States of Mato Grosso and Mato Grosso do Sul (MOURÃO et al., 2010). Crab-eating foxes (Canidae: Cerdocyon thous) and brown-nosed coatis (Procyonidae: Nasua nasua) are common species in the region and widespread in Brazil. The crab-eating fox and brown-nosed coati are generalist, feeding on fruits, insects, and small vertebrates (GOMPPER \& DECKER, 1998; BIANCHI et al., 2013).

A serologic investigation of free-ranging crab-eating foxes and brown-nosed coatis was conducted in the Nhecolândia sub-region of Brazilian Pantanal, Mato Grosso do Sul State, Brazil, to evaluate the epidemiologic pattern of anti-smooth Brucella antibodies in these wild populations. The study was conducted in the Nhumirim Ranch, a research station of Embrapa, (Brazilian Agricultural Research Corporation) of around $4,400 \mathrm{ha}$, located $160 \mathrm{~km}$ east from the municipality of Corumbá, Brazil. There, cattle are raised among areas of wildlife preservation and $\boldsymbol{B}$. abortus-infected cattle have already been identified (CHATE et al., 2009).

Blood samples were obtained by femoral vein puncture from anesthetized animals. From 2005 to 2009,41 sera from 38 crab-eating foxes (21 males and 17 females) and 35 from 34 brown-nosed coatis ( 24 males and 10 females) were sampled under licenses of Instituto Brasileiro do Meio Ambiente e Recursos Naturais Renováveis (IBAMA) (Brazilian Institute for Environment and Natural Resources). Gender and age-class were determined for all animals (OLIFIERS et al., 2010). Serum was separated by centrifugation and stored at $-18^{\circ} \mathrm{C}$ until analysis. Antismooth Brucella antibodies were screened by the Rosa Bengal Test (RBT) (Tecpar, Brazil) (ALTON et al.,
1988) and confirmed by the Fluorescence Polarization Assay (FPA) (Diachemix, USA) (NIELSEN et al., 2000). Exact Clopper-Pearson confidence interval for a single binomial proportion was calculated by the $\mathrm{R}$ package binGroup (ZHANG et al., 2011). Association between brucellae serological status and gender or age was analyzed by the chi-square and Fisher exact tests $(\alpha=0.05)$ (SAMPAIO, 2002), using the software Epi-Info 6.04 (DEAN et al., 2011).

The frequency of smooth Brucella seropositive animals in both tests (screening and confirmatory) were $13.2 \%(5 / 38,95 \%$ CI: $4.4 \%$ $28.1 \%$ ) for crab-eating foxes and $8.8 \%(3 / 34,95 \%$ CI: $1.9 \%-23.7 \%$ ) for brown-nosed coatis. Of the five Brucella spp. seropositive crab-eating foxes, four were females and one was male; of the three positive brown-nosed coatis, one was female and two were males. No gender association with brucellae serology was observed $\left(\chi^{2}=0.67, \mathrm{df}=1, \mathrm{P}=0.41\right.$ for $\boldsymbol{C}$. thous and Fisher's exact test $\mathrm{P}=0.20$ for $\boldsymbol{N}$. nasua). Only one juvenile crab-eating fox was serologic positive for brucellosis; all other positive animals were adults. No association was found between seropositivity for Brucella spp. and age $\left(\chi^{2}=0.80, \mathrm{df}=1, \mathrm{P}=0.37\right.$ for $\boldsymbol{C}$. thous and Fisher's exact test $\mathrm{P}=1.00$ for $N$. nasua). Three crab-eating foxes, one sampled as juvenile and as adult, and one brown-nosed coati were each sampled twice, six to ten month apart, and showed negative results on both occasions.

Those results showed serologic evidence of exposure to or infection of crab-eating foxes and brown-nosed coatis by Brucella spp. Furthermore, the omnivorous diet of crab-eating foxes and brownnosed coatis, which could include aborted fetus and placental membranes, extremely rich in Brucella spp. (CORBEL et al., 2006; BIANCHI et al., 2013), could increase the risk of infection. In South America, there is serologic evidence of infection by $\boldsymbol{B}$. abortus in hoary fox (Pseudalopex vetulus) (AZEVEDO et al., 2010), and capybara (Hydrochaeris hydrochaeris) (LORD \& FLORES, 1983), as well as isolation of the agent from the Pampas fox (Pseudalopex gymnocercus) and the South American grey fox (P. griseus) (SZYFRES \& GONZÁLEZ TOMÉ, 1966). Although infection was not confirmed by isolation of Brucella spp. from the studied animals, the chosen serological strategy, employing serial testing with RBT and FPA, made the diagnosis highly specific (GODFROID, 2002). Mato Grosso do Sul State, where Nhecolândia is located, presents one of the largest prevalence of cattle herds infected by $\boldsymbol{B}$. abortus $(41.5 \%)$ in Brazil (CHATE et al., 2009). There, the extensive raising of large beef herds, cooccurring with wildlife - including crab- 
eating foxes and brown-nosed coatis - is common. The high prevalence of brucellosis in cattle in this region (CHATE et al., 2009) can facilitate the introduction of the disease in susceptible sympatric wild animals. Moreover, B. abortus and $\boldsymbol{B}$. suis were isolated from cattle in this region (POESTER et al., 2002). Conversely, canids were associated with the spreading of the brucellosis in other continents (VAN CAMPEN \& RHYAN, 2010), and experimental studies demonstrated that coyotes (Canis latrans) were capable of transmitting brucellosis to cattle (DAVIS et al., 1988). In Pantanal, the crab-eating fox and the brown-nosed coati could be playing this role in the spreading of the infection. Frequently, wildlife species are resistant to the disease and may even be silent carriers of the infection (BENGIS et al., 2002). The importance of livestock/wildlife interface for brucellosis transmission and persistence in a given area depends on the combination of several factors as host susceptibility, infectious dose, contact rates between infected and susceptible animals, and environment characteristics (GODFROID, 2002; BENGIS et al., 2002; VAN CAMPEN \& RHYAN, 2010).

Although a higher Brucella spp. infection rate could be expected for adult animals, due to a longer exposure time, no age difference was observed in this study for crab-eating foxes, probably due to the small number of seropositive animals observed, which precluded age comparisons. In the case of brown-nosed coatis, only adult animals were studied. Likewise, no significant difference in seropositivity between sexes was observed, but the frequency of seropositive animals was small and the statistical power of the test was therefore low.

In North America and Europe, wildlife species such as bison, elk and feral swine were characterized as reservoirs of Brucella spp., hampering its eradication (VAN CAMPEN \& RHYAN, 2010). Demonstrating the presence of wild reservoirs requires a complete overhaul of the strategies previously used to control brucellosis in livestock so that the impacts of the disease are minimized in both populations. Currently, Brazil is undertaking a brucellosis control program in cattle and water buffaloes that will soon turn into an eradication program in some regions. Thus, identification of Brucella spp. reservoirs among wild species is of major importance for defining eradication strategies in the country.

Another aspect that must be considered is the conservation of wildlife, as the expansion of cattle ranching over natural habitats will lead to the increase of interface between livestock and wild animals therefore increasing the chances of mutual disease transmission (BENGIS et al., 2002). Populations of wild animals can be adversely affected by the introduction of new infectious agents (MEDINA-VOGEL, 2010), and appropriate animal health is a goal for the livestock as well as wildlife conservationists (BENGIS et al., 2002).

The results of this study suggest exposure to or infection of crab-eating fox and brown-nosed coati from the Brazilian Pantanal by Brucella spp. It remains to be investigated whether these species are reservoirs for brucellosis and whether infection adversely affects their health. It is therefore critical for the Brazilian program on the control and eradication of brucellosis to define the role of wild species on the epidemiology of brucellosis. At the same time, conservation actions must take into account the circulation of brucellosis among wild mammals and the impact it may have on wildlife health.

\section{ACKNOWLEDGMENTS}

A. P. Lage and E. M. S. Dorneles were indebted to Conselho Nacional de Desenvolvimento Científico e Tecnológico (CNPq) for their fellowships. RCB was a recipient of doctoral fellowship from Coordenação de Aperferiçoamento do Pessoal de Nível Superior (Capes). This study was supported by $\mathrm{CNPq}$, Fundação de Amparo à Pesquisa do Estado de Minas Gerais (Fapemig), FEP - MVZ Coordenação Preventiva, Fundect, Embrapa Macro, University of Missouri, FIOCRUZ and Earthwatch Institute.

\section{BIOETHICS AND BIOSSECURITY COMMITTEE APPROVAL}

\#11772-2.

Processes \#003/2006, \#100/2006, \#11772-1 and

\section{REFERENCES}

ALTON, G.G. et al. Techniques for the Brucellosis Laboratory. Paris: Institut National de La Recherche Agronomique, 1988. 190p.

AZEVEDO, S.S. et al. Anticorpos anti-Brucella abortus, anti Brucella canis e anti-Leptospira spp. em raposas (Pseudalopex vetulus) do semiárido paraibano, Nordeste do Brasil. Ciência Rural, v.40, n.1, p.190-192, 2010. Available from: <http://www. scielo.br/pdf/cr/v40n1/a404cr1939.pdf>. Accessed: Set. 18, 2012. doi: 10.1590/S0103-84782009005000232.

BENGIS, R.G. et al. Infectious animal diseases: the wildlife/ livestock interface. Revue Scientifique et Technique - Office international des épizooties, v.21, n.1, p.53-65, 2002. Available from: 〈http://www.oie.int/doc/ged/d522.pdf〉. Accessed: Set. 18, 2012 .

BIANCHI, R.C. et al. Intraspecific, interspecific, and seasonal differences in the diet of three mid-sized carnivores in a large neotropical wetland. Acta Theriologica, v.13, n.53, p.2001-2013, 
2013. Available from: <http://link.springer.com/article/10.1007/ s13364-013-0137-x>. Accessed: Out. 20, 2013. doi: 10.1007/ s13364-013-0137-x.

CHATE, S.C. et al. Situação epidemiológica da brucelose bovina no Estado do Mato Grosso do Sul. Arquivo Brasileiro de Medicina Veterinária e Zootecnia, v.61, supl.1, p.46-55, 2009. Available from: <http://www.scielo.br/pdf/abmvz/v61s1/ a07v61s1.pdf>. Accessed: Set. 18, 2012. doi: 10.1590/S010209352009000700007.

CORBEL, M.J. et al. Brucellosis in humans and animals. Geneva: World Health Organization, 2006. 89p.

DAVIS, D.S. et al. Interspecific transmission of Brucella abortus from experimentally infected coyotes (Canis latrans) to parturient cattle. Journal of Wildlife Disease, v.24, n.3, p.533-537, 1988. Available from: <http://www.jwildlifedis.org/content/24/3/533.full. pdf>. Accessed: Out. 20, 2012. doi: 10.7589/0090-3558-24.3.533.

DEAN, A.G. et al. Epi Info ${ }^{\text {TM}}$ : a word processing, database and statistics program for epidemiology on micro-computers. Atlanta: Center for Disease Control, 2011. Available from: <http://www. cdc.gov/epiinfo>. Acessed: April. 24, 2012.

GODFROID, J. Brucellosis in wildlife. Revue Scientifique et Technique - Office international des épizooties, v.21, n.2, p.277286, 2002. Disponível em: <http://www.oie.int/doc/ged/D514. PDF>. Acesso em: Out. 22, 2012

GOMPPER, M.E.; DECKER, D.M. Nasua nasua. Mammalia Species, n.580, p.1-9, 1998. Available from: <http://www.science. smith.edu/msi/pdf/i0076-3519-580-01-0001.pdf>. Accessed: Out. 22,2012

LORD, V.R.; FLORES, R. Brucella spp. from capybara (Hydrochaeris hydrochaeris) in Venezuela: Serologic studies and metabolic characterization of isolates. Journal of Wildlife Disease, v.19, n.4, p.308-314, 1983. Disponível em: <http://www. jwildlifedis.org/content/19/4/308.full.pdf>. Accessed: Out. 2, 2012.

MEDINA-VOGEL, G. Ecología de enfermidades infecciosas emergentes y conservación de espécies silvestres. Archivos de Medicina Veterinaria, v.42, n.1, p.11-24, 2010. Available from: <http://www.scielo.cl/scielo.php?pid=S0301-732X20100001 $00003 \&$ script $=$ sci_arttext $>$. Accessed: Out. 29, 2012. doi: 10.4067/S0301-732X2010000100003.

MOURÃO, G. et al. How much can the number of jabiru stork (Ciconiidae) nests vary due to change of flood extension in a large neotropical floodplain? Zoologia, v.27, p.751756, 2010. Available from: <http://www.scielo.br/scielo. php? script $=$ sci_arttext $\&$ pid $=$ S 1984-46702010000500012>. Accessed: Out. 9, 2012. doi: 10.1590/S198446702010000500012 .

NIELSEN, K. et al. Fluorescent polarization immunoassay: detection of antibody to Brucella abortus. Methods, v.22, n.1, p.71-76, 2000. Available from: <http://www.sciencedirect.com/ science/article/pii/S1046202300910387>. Accessed: Out. 9, 2012. doi: 10.1006/meth.2000.1038.

OLIFIERS, N. et al. Estimating age of carnivores from the Pantanal region of Brazil. Wildlife Biology, v.16, n.4, p.389399, 2010. Disponível em: <http://www.bioone.org/doi/ abs/10.2981/09-104? journalCode=wbio>. Accessed: Nov. 19, 2012. doi: 10.2981/09-104.

POESTER, F.P. et al. Brucellosis in Brazil. Veterinary Microbiology, v.90, n.1-4, p.55-62, 2002. Available from: <http:// www.sciencedirect.com/science/article/pii/S0378113502002456>. Accessed: Nov. 19, 2012.

SAMPAIO, I.B.M. Estatística aplicada à experimentação animal. Belo Horizonte: Fundação de Ensino e Pesquisa em Medicina Veterinária e Zootecnia, 2002. 265p.

SIKUSAWA, S. et al. Situação epidemiológica da brucelose bovina no Estado de Santa Catarina. Arquivo Brasileiro de Medicina Veterinária e Zootecnia, v.61, supl.1, p.103-108, 2009. Available from: <http://www.scielo.br/pdf/abmvz/v61s1/ a13v61s1.pdf>. Accessed: Nov. 19, 2012. doi: 10.1590/S010209352009000700013.

SZYFRES, B.; GONZÁLEZ TOMÉ, J. Natural Brucella infection in Argentine wild foxes. Bull WHO, v.34, p.919-923, 1966. Available from: <http://www.ncbi.nlm.nih.gov/pmc/articles/PMC2476051/ pdf/bullwho00615-0109.pdf>. Accessed: Nov. 1, 2012.

VAN CAMPEN, H.; RHYAN, J. The role of wildlife in disease of cattle. Veterinary Clinics of North America: Food Animal Practice, v.26, n.1, p.147-161, 2010. Available from: <http://linkinghub.elsevier.com/retrieve/pii/S07490720(09)00106-6>. Accessed: Nov. 1, 2012. doi: 10.1016/j. cvfa.2009.10.008

ZHANG, B. et al. binGroup: Evaluation and experimental design for binomial group testing. R package version 1.0-8, 2011. Accessed: Jul. 2012. Online. Available from: <http://CRAN.Rproject.org/package $=$ binGroup $>$. 